\title{
Synthetic strategies for pyrrolo[2,1-f][1,2,4]triazine: the parent moiety of antiviral drug remdesivir
}

\author{
Gaurav S. Rai ${ }^{1}$, Jayesh J. Maru ${ }^{1 *}$ \\ ${ }^{1}$ Department of Chemistry, University School of Sciences, Gujarat University, \\ Ahmedabad-380009,Navrangpura, India; e-mail: jaymaru@gujaratuniversity.ac.in
}

Published in Khimiya Geterotsiklicheskikh Soedinenii,

Submitted May 22, 2020

2020, 56(12), 1517-1522

Accepted July 6, 2020

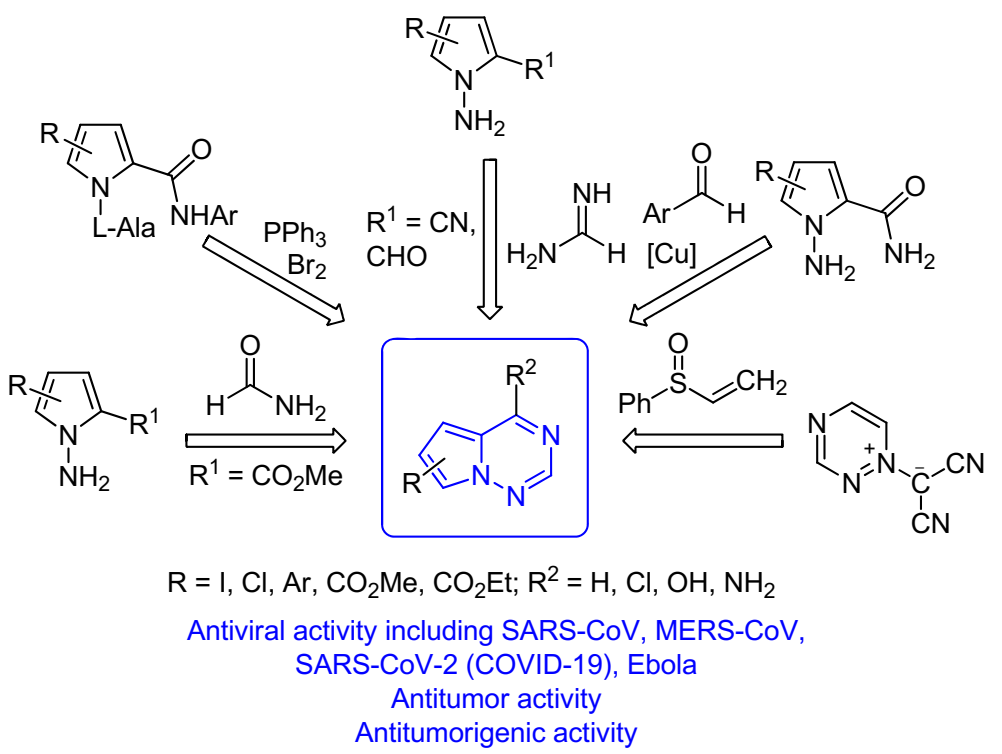

This review summarizes diverse synthetic protocols for the preparation of pyrrolo[2,1- $f][1,2,4]$ triazine derivatives, covering literature sources from the past two decades. For effective representation, the synthetic methods toward the title compound are classified into six distinct categories: 1) synthesis from pyrrole derivatives, 2) synthesis via bromohydrazone, 3) synthesis via formation of triazinium dicyanomethylide, 4) multistep synthesis, 5) transition metal mediated synthesis, and 6) rearrangement of pyrrolooxadiazines. A brief outline of all optimized schemes is provided with relevant examples.

Keywords: pyrrolo[2,1-f][1,2,4]triazine, remdesivir, anti-norovirus activity, antiviral drug, COVID-19, kinase inhibitor.

Pyrrolo[2,1-f][1,2,4]triazine, a unique bicyclic heterocycle, containing $\mathrm{N}-\mathrm{N}$ bond with a bridgehead nitrogen, possesses numerous activities against diverse therapeutic targets. It was first synthesized in late 1970s, but did not find many applications thereafter. A broad-spectrum antiviral drug remdesivir (Fig. 1) has been recently recognized against wide array of RNA viruses (including SARS/MERS-CoV) and has shown encouraging results in the treatment of recently emerged novel coronavirus (COVID-19). ${ }^{1}$ This medication, containing pyrrolo[2,1-f]$[1,2,4]$ triazine as an active moiety, has recently been approved (by US FDA in May 2020) for the emergency treatment of people having severe symptoms of COVID-19.
Also, pyrrolo[2,1-f][1,2,4]triazine is an active structural motif of other drugs such as brivanib alaninate (Fig. 1, antitumorigenic drug, approved by US FDA in 2011), BMS-690514, and BMS-599626 (EGFR inhibitor in clinical phase II) and many others.

Meanwhile, different studies in the field of drug research have shown promising potential of pyrrolo[2,1-f][1,2,4]triazine derivatives and attracted considerable interest among medicinal chemists because of their versatility, with a wide range of biological activities. These include Eg5 inhibitor, ${ }^{2}$ VEGFR-2 inhibitors, ${ }^{3}$ anticancer agents as dual inhibitors of c-Met/VEGFR-2, ${ }^{4}$ EGFR inhibitor slowing cellular proliferation of the human colon tumor cell line, ${ }^{5}$ 

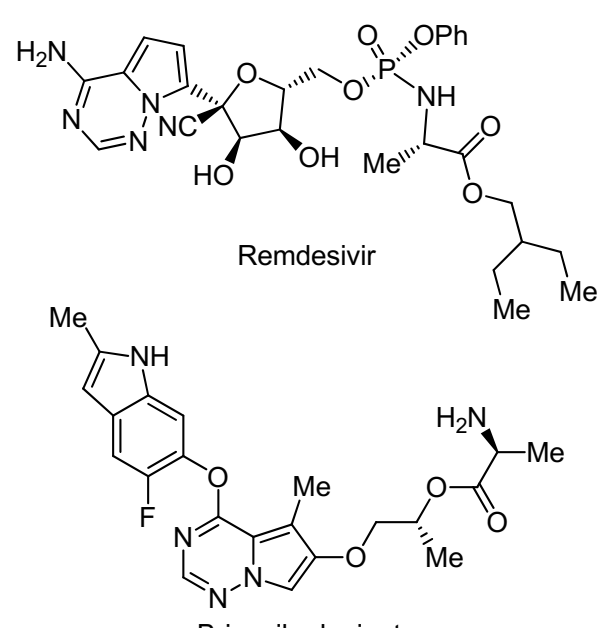

Brivanib alaninate

Figure 1. Drugs containing pyrrolo[2,1-f][1,2,4]triazine moiety.

anaplastic lymphoma kinase (ALK) inhibitor, ${ }^{6}$ IGF-1R and IR kinase inhibitor, ${ }^{7}$ pan-Aurora kinase inhibitor, ${ }^{8}$ EGFR and HER2 protein tyrosine dual inhibitor, ${ }^{9}$ and hedgehog (Hh) signaling pathway inhibitor. ${ }^{10}$ Some analogs of pyrrolo[2,1-f][1,2,4]triazine have been used in the treatment of Ebola and other emerging viruses. ${ }^{11}$ Recent reports have revealed anti-norovirus activity of 4-aminopyrrolo$[2,1-f][1,2,4]$ triazine $C$-nucleosides, which have the ability to inhibit both murine and human norovirus RNAdependent RNA polymerase $(\mathrm{RdRp}) .{ }^{12}$ Owing to the importance of this heterocycle, this review attempts to summarize different synthetic strategies adopted for pyrrolo[2,1-f][1,2,4]triazine over the past two decades. The aim is to be more illustrative rather than exhaustive in representing the reported work.

\section{Synthesis from pyrrole derivatives}

A facile synthesis of pyrrolo[2,1-f][1,2,4]triazines was described starting from the $N$-unsubstituted pyrrole derivative $1 .{ }^{13}$ Treating pyrrole 1 with either $O$-(2,4-dinitrophenyl)hydroxylamine $\left(\mathrm{DnpONH}_{2}\right)$ or $\mathrm{NH}_{2} \mathrm{Cl}$ in the presence of $\mathrm{NaH}$, followed by cyclization with formamide at $165^{\circ} \mathrm{C}$, yielded pyrrolotriazine 2 (Scheme 1).

\section{Scheme 1}

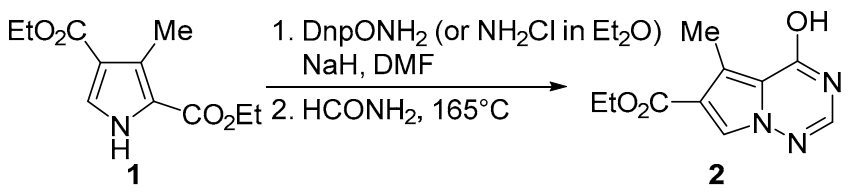

Synthesis of pyrrolotriazine 6 from 3-iodo- $1 H$-pyrrole2-carbaldehyde (3) has also been reported. ${ }^{14}$ The latter was transformed into pyrrole-2-carbonitrile 4 through a twostep one-pot process via the corresponding oxime. Electrophilic $\mathrm{N}$-amination of compound $\mathbf{4}$, followed by cyclization of the resulting $\mathrm{N}$-aminopyrrole 5 with triethyl orthoformate, yielded pyrrolotriazine $\mathbf{6}$ (Scheme 2).

Aminopyrrole 8 was obtained by $\mathrm{N}$-amination of diethyl 3-isopropyl-1H-pyrrole-2,4-dicarboxylate (7) using either $O$-(diphenylphosphinyl)hydroxylamine or $O$-(mesitylenesulfonyl)hydroxylamine. Cyclization of compound $\mathbf{8}$ at
Scheme 2

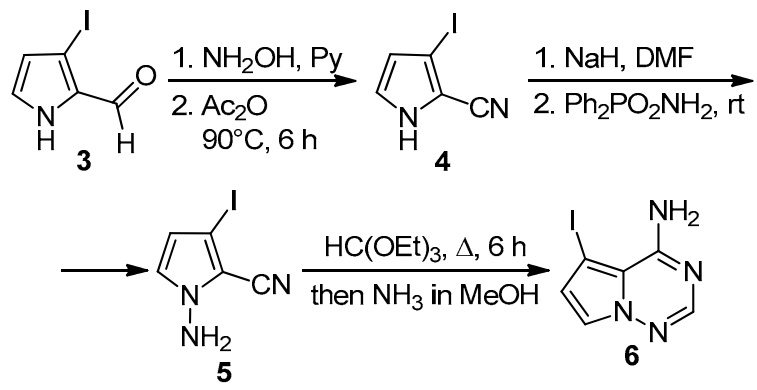

$165^{\circ} \mathrm{C}$ in DMF yielded bicyclic compound 9. The latter was deoxidized by heating with $\mathrm{POCl}_{3}$ to give ethyl 4-chloro5-(propan-2-yl)pyrrolo[2,1-f][1,2,4]triazine-6-carboxylate (10) in high yield (Scheme 3$)^{15}$

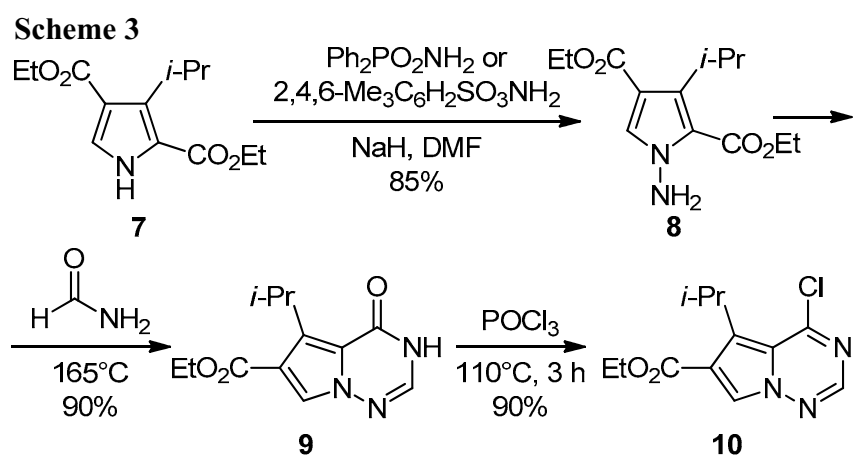

2-Arylaminopyrrolo[2,1-f][1,2,4]triazine 17 was synthesized as a new kinase inhibitor template starting from 7-bromo-2-(methylsulfanyl)pyrrolo[2,1-f][1,2,4]triazine (16) via orthogonal approaches. ${ }^{16}$ To obtain compound 16, $\mathrm{N}$-amination of methyl pyrrole-2-carboxylate (11) was carried out using a suitable aminating agent $\left(\mathrm{NH}_{2} \mathrm{Cl}\right)$ to introduce the key N-N bond. Subsequent treatment of the obtained crude material with benzoyl isothiocyanate produced pyrrole 12. Hydrolytic cyclization in $2 \mathrm{M} \mathrm{NaOH}$ followed by $S$-methylation gave bicyclic compound $\mathbf{1 3}$. $\mathrm{POCl}_{3}$ was then used to block the highly reactive C-4 position giving rise to chlorinated product 14 . Bromination of compound 14 with NBS proceeded smoothly at the C-7 atom to give compound $\mathbf{1 5}$ with reasonable regioselectivity for the C-7 vs C-5 position ( $\sim 5: 1)$. Further treatment of the crude compound 15 with $\mathrm{NaBH}_{4}$ led to the dechlorination and partial reduction of the heterocycle. Finally, oxidation with DDQ restored the aromaticity to give compound $\mathbf{1 6}$ in good yield (Scheme 4).

Additionally, synthesis of 7-phenylpyrrolo[2,1-f][1,2,4]triazin-2-ol (23) from pyrrole derivative 18 was also reported. ${ }^{15}$ Initially, dibromopyrrole 19 was obtained from pyrrole 18 using 1,3-dibromo-5,5-dimethylhydantoin (DBDMH) along with NMP to increase the yield. Halogenmetal exchange reaction of compound 19 with $i-\mathrm{PrMgCl} \cdot \mathrm{LiCl}$ followed by the treatment with $\mathrm{DMF}$ resulted in the formation of 5-bromopyrrole-2-carbaldehyde 20. The latter was subjected to the Suzuki coupling yielding compound $\mathbf{2 1}$ which was alkylated with phenyl chloroformate in the presence of NaHMDS to give 


\section{Scheme 4}<smiles>COC(=O)c1ccc[nH]1</smiles>

11

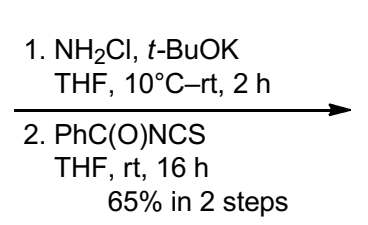<smiles>COC(=O)c1cccn1NC(=S)NC(=O)c1ccccc1</smiles>

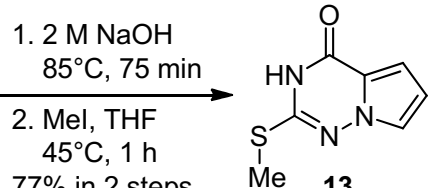

$45^{\circ} \mathrm{C}, 1 \mathrm{~h}$

$77 \%$ in 2 steps
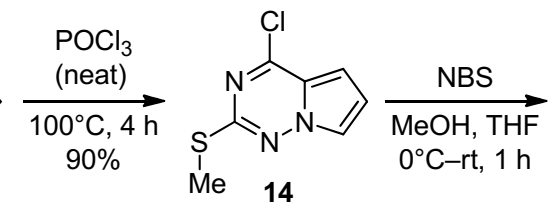

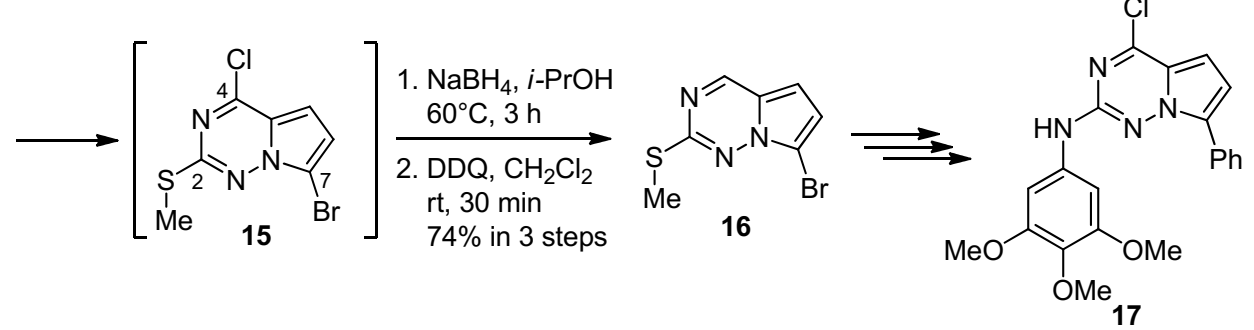

Scheme 5

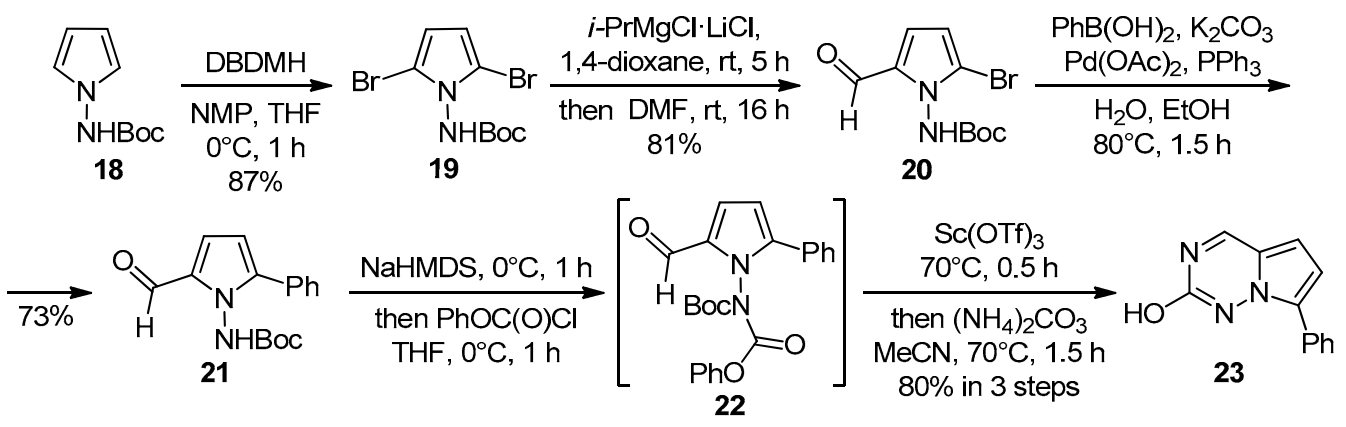

compound 22. For the selective cleavage of $N$-Boc protective group, $\mathrm{Sc}(\mathrm{OTf})_{3}$ was used, and subsequent condensation with $\left(\mathrm{NH}_{4}\right)_{2} \mathrm{CO}_{3}$ resulted in the triazine cycle formation to provide the requisite product $\mathbf{2 3}$ (Scheme 5).

Wang et al. reported the synthesis of chlorinated derivative of pyrrolo[2,1- $f][1,2,4]$ triazine 29 starting from $\beta$-substituted acrylate $24 .{ }^{17}$ Cycloaddition of tosylmethyl isocyanide (TosMIC) with compound $\mathbf{2 4}$ in the presence of $\mathrm{NaH}$ gave pyrrole derivative $\mathbf{2 5}$ which was further acylated with trichloroacetyl chloride at the C-2 position to afford substituted pyrrole $\mathbf{2 6}$ in high yield. Reaction of compound 26 with $\mathrm{NaOMe}$ and convenient and more economical $\mathrm{N}$-amination with $\mathrm{NH}_{2} \mathrm{Cl}$ instead of $\mathrm{O}$-(diphenylphosphinyl)hydroxylamine or $O$-(mesitylenesulfonyl)hydroxylamine was accomplished. ${ }^{15}$ Cyclization of $\mathrm{N}$-aminopyrrole 27 with formamide afforded 1,2,4-triazine 28. Chlorination of 1,2,4-triazine 28 with $\mathrm{POCl}_{3}$ yielded product 29 (Scheme 6).

\section{Scheme 6}

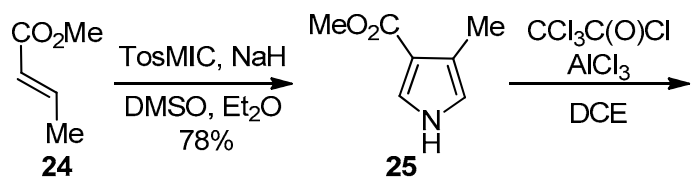<smiles>COC(=O)c1c[nH]c(C(=O)OCc2ccccc2)c1C(=O)OCc1cn(N)c(C(=O)OC)c1C</smiles>

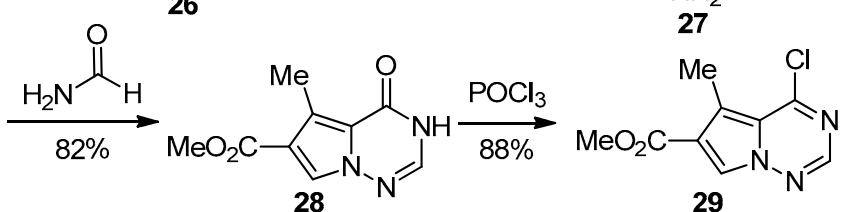

\section{Synthesis via bromohydrazone}

A practical six-step synthesis of pyrrolotriazine scaffold has been described. ${ }^{18}$ The condensation of 2-bromo-1,1-dimethoxyethane (30) with $\mathrm{NH}_{2} \mathrm{NHCbz}$ under acidic conditions gave bromohydrazone 31 (Scheme 7). Different acids, such as $\mathrm{HCl}, \mathrm{H}_{2} \mathrm{SO}_{4}$, methanesulfonic acid (MSA), TFA, $\mathrm{H}_{3} \mathrm{PO}_{4}$, and $\mathrm{AcOH}$ were tested as additives to facilitate the condensation reaction. However, the cleanest and fastest reaction was realized in the presence of concentrated $\mathrm{H}_{3} \mathrm{PO}_{4}$. The next transformation included $C$-alkylation of sodium 1,4-diethoxy-1,4-dioxobut-2-en-

Scheme 7

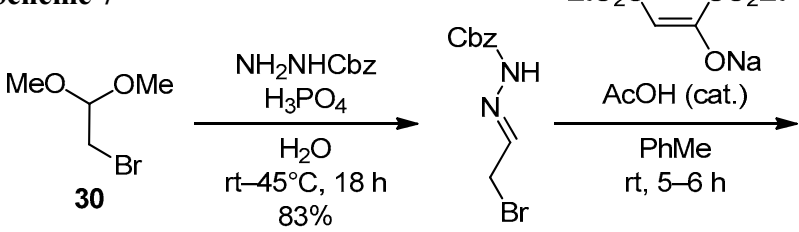

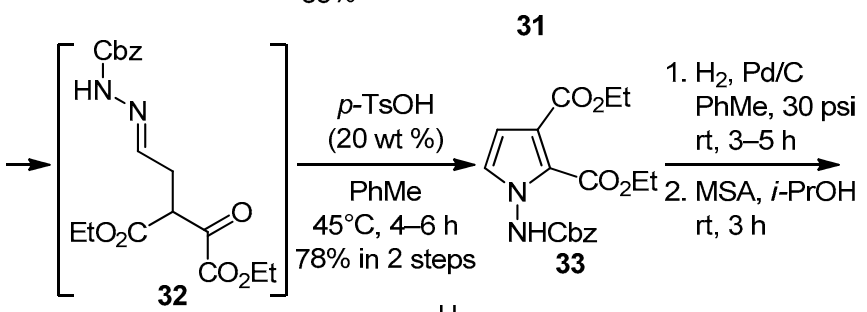

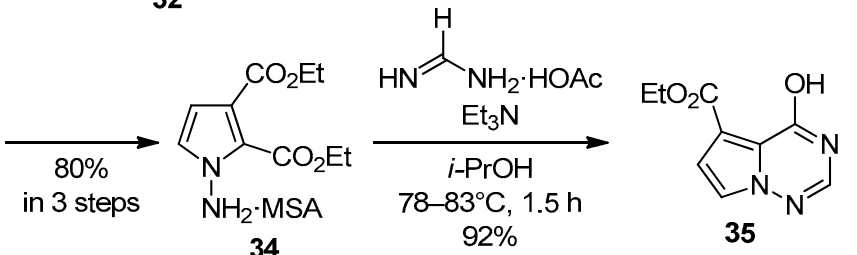


2-olate with bromide $\mathbf{3 1}$ to afford keto ester derivative $\mathbf{3 2}$. It was also observed that the use of less polar solvents for this transformation afforded higher yield of the alkylated product. Acid-catalyzed cyclization of compound 32 followed by heating at $45^{\circ} \mathrm{C}$ afforded protected 1-aminopyrrole 33. Removal of the Cbz group via hydrogenolysis resulted in 1-aminopyrrole 34. Reaction of 1-aminopyrrole 34 with formamidine acetate, which acted both as a reagent and a solvent in the presence of $\mathrm{Et}_{3} \mathrm{~N}$, led to the triazine cycle annulation and formation of pyrrolotriazine 35 in high yield (Scheme 7).

\section{Synthesis via formation of triazinium dicyanomethylide}

A convenient two-step synthesis of pyrrolo[2,1-f][1,2,4]triazine 38 as a precursor of highly permeant IRAK4 inhibitors was reported. ${ }^{19}$ Initially, tetracyanoethylene oxide was reacted with triazine $\mathbf{3 6}$ to afford triazinium dicyanomethylide 37. Subsequently, [2+2] cycloaddition of phenyl vinyl sulfoxide provided the formation of 2-(methylsulfanyl)pyrrolo[2,1-f][1,2,4]triazine-7-carbonitrile (38) (Scheme 8).

\section{Scheme 8}<smiles>C=C[C@H](C)C(=O)O[Mg]</smiles>

\section{Multistep synthesis}

Nucleoside analogs are an important class of antivirals and are used in the treatment of hepatitis $\mathrm{C}$ virus as they exhibit cross genotype activity and a high barrier to resistance. Besides, C-nucleosides have shown enhanced metabolism and pharmacokinetic properties compared to the N-nucleosides mainly due to the presence of a strong $\mathrm{C}-\mathrm{C}$ glycosidic bond and a nonnatural heterocyclic base. Pyrrolo$[2,1-f][1,2,4]$ triazine-4-amine adenosine analog $\mathbf{4 5}$ was synthesized via a linear 7-step route (Scheme 9). ${ }^{20}$ Initially, the activated trichloroacetamidate $\mathbf{4 0}$ was obtained from trichloroacetonitrile and riboside 39. Subsequent slow addition of pyrrole at low temperature in the presence of $\mathrm{BF}_{3} \cdot \mathrm{Et}_{2} \mathrm{O}$ gave an anomeric mixture of pyrrole nucleosides 41. A mixture of anomers was separated and pure $\beta$-anomer 42 was obtained using chlorosulfonyl isocyanate in DMF. Electrophilic $\mathrm{N}$-amination of pyrrole derivative $\mathbf{4 2}$ with $O$-(diphenylphosphinyl)hydroxylamine yielded $N$-aminopyrrole 43. Cyclization of $N$-aminopyrrole 43 in the presence of formamidine acetate resulted in the formation of substituted pyrrolo[2,1-f][1,2,4]triazin-4-amine $\mathbf{4 4}$ which under buffer hydrogenolysis conditions formed free pyrrolotriazine-containing adenosine analog 45 .

Pyrrolo[2,1-f][1,2,4]triazines 51 were synthesized in a multistep procedure using pyridine derivative and $\mathrm{N}$-aminated pyrrole. The obtained derivatives showed antiproliferative activity against human cancer cells. ${ }^{21}$ 2-Aminopyridine $\mathbf{4 6}$ was brominated and then converted into substituted pivaloylamide 47 (Scheme 10). Reaction of amide 47 with

Scheme 9

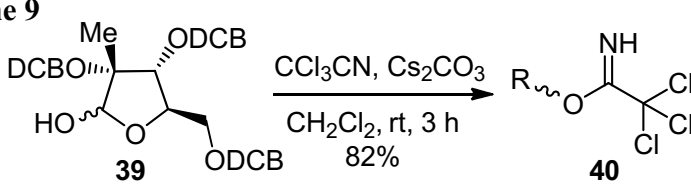

39<smiles>CCCCPc1ccc(C#N)[nH]1</smiles>

42
$\underset{\mathrm{THF}, 0^{\circ} \mathrm{C}, 0.5 \mathrm{~h}}{\stackrel{\mathrm{Ph}_{2} \mathrm{P}(\mathrm{O}) \mathrm{ONH}_{2}}{\mathrm{NaH}}}$<smiles>[R]c1ccc(C#N)n1N</smiles>
43

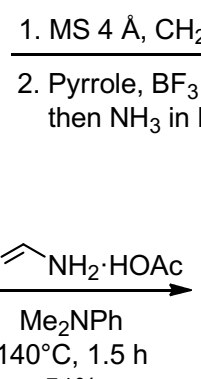
$51 \%$

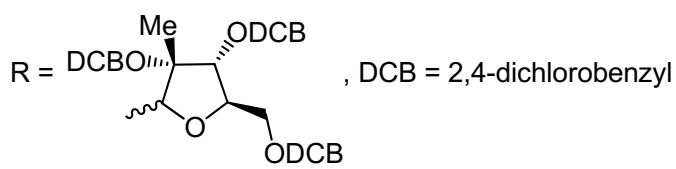

Scheme 10

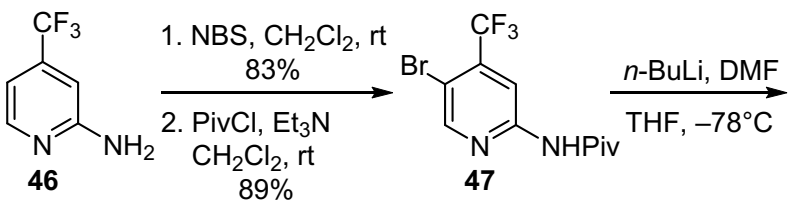

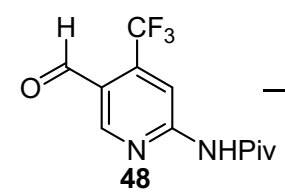<smiles>[R]c1cc(C(=O)OCC)[nH]c1[R]</smiles>

1. $\mathrm{NH}_{4} \mathrm{Cl}, \mathrm{K}_{2} \mathrm{CO}_{3}, \mathrm{NH}_{4} \mathrm{OH}$ Aliquat 336, $\mathrm{NaClO}, \mathrm{MTBE}, 0^{\circ} \mathrm{C}$ 2. $\mathrm{NH}_{3}$ in $\mathrm{MeOH}, 80^{\circ} \mathrm{C}$ 49 $\mathrm{R}^{1}=\mathrm{H}, \mathrm{CN} ; \mathrm{R}^{2}=\mathrm{CN}, \mathrm{CO}_{2} \mathrm{Me}$<smiles>[R]c1cc(C(N)=O)n(N)c1[R]</smiles>

50 
$n$-BuLi and DMF afforded the key intermediate 48. $\mathrm{N}$-Amination of pyrroles $\mathbf{4 9}$ was realized in the presence of quaternary ammonium salt and $\mathrm{NH}_{4} \mathrm{Cl}$ in MTBE giving 1-amino-1 $H$-pyrrole-2-carboxamides $\mathbf{5 0}$ after treatment with $\mathrm{NH}_{3}$ in $\mathrm{MeOH}$. Finally, Cu-catalyzed coupling of pyridine-3-carbaldehyde $\mathbf{4 8}$ with $\mathrm{N}$-aminopyrroles $\mathbf{5 0}$ afforded pyrrolotriazines 51 (Scheme 10).

\section{Transition metal mediated synthesis}

A one-pot two-step synthesis of substituted pyrrolo[2,1-f]$[1,2,4]$ triazin-4(3H)-ones 55 and $\mathbf{5 6}$, in which at least six bonds were formed, have been proposed by Yang group. ${ }^{22}$ $\mathrm{The} \mathrm{Cu}(\mathrm{II})$-catalyzed reaction of 4-oxo- $4 H$-chromene3 -carbaldehyde (52) and 1-amino-1H-pyrrole-2-carboxamide (53) gave 2-(4-oxo- $4 H$-chromen-3-yl)pyrrolo[2,1-f]$[1,2,4]$ triazin-4(3H)-one (54). The best result was achieved using the $\mathrm{CuCl}_{2} \cdot 2 \mathrm{H}_{2} \mathrm{O} / \mathrm{NaOAc} / \mathrm{DMSO}$ catalytic system at $120^{\circ} \mathrm{C}$. Intermediate 54 reacted with different amidines and hydrazines in the presence of $\mathrm{NaOAc}$ yielding pyrrolo$[2,1-f][1,2,4]$ triazin-4(3H)-ones 55 and 56, respectively (Scheme 11).

\section{Scheme 11}

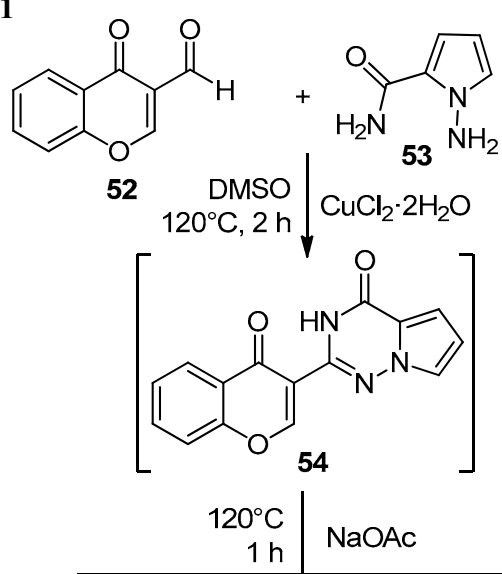

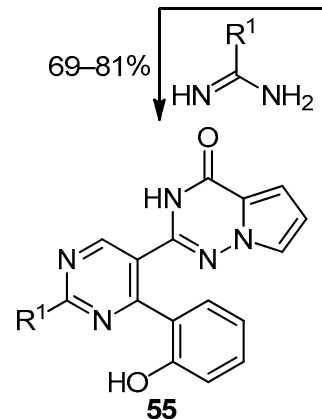

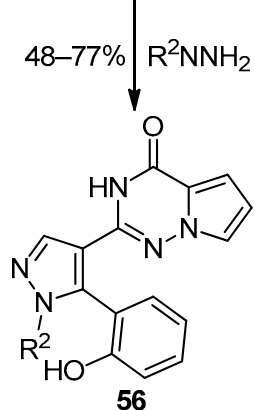

$\mathrm{R}^{1}=\mathrm{H}, \mathrm{Me}, i-\mathrm{Pr}, t-\mathrm{Bu}, 4-\mathrm{MeOC}_{6} \mathrm{H}_{4}, 4-\mathrm{MeC}_{6} \mathrm{H}_{4}, 4-\mathrm{ClC}_{6} \mathrm{H}_{4}, 4-\mathrm{BrC}_{6} \mathrm{H}_{4}$, 4- $\mathrm{H}_{2} \mathrm{NC}_{6} \mathrm{H}_{4}, 2-\mathrm{MeC}_{6} \mathrm{H}_{4}, 3-\mathrm{MeOC}_{6} \mathrm{H}_{4}$

$\mathrm{R}^{2}=\mathrm{Me}, i-\mathrm{Pr}, t-\mathrm{Bu}, \mathrm{Ph}, 4-\mathrm{MeC}_{6} \mathrm{H}_{4}, 4-\mathrm{MeOC}_{6} \mathrm{H}_{4}, 4-\mathrm{FC}_{6} \mathrm{H}_{4}$, 4- $\mathrm{ClC}_{6} \mathrm{H}_{4}, 4-\mathrm{BrC}_{6} \mathrm{H}_{4}, 4-\mathrm{F}_{3} \mathrm{CC}_{6} \mathrm{H}_{4}, 4-\mathrm{NCC}_{6} \mathrm{H}_{4}$

A similar approach was reported for the synthesis of isoquinoline-fused pyrrolotriazines $\mathbf{5 8}$ via condensation of compound 53 with 2-alkynylbenzaldehydes $\mathbf{5 7}$ in the presence of $\mathrm{Cu}(\mathrm{II})$ catalyst (Scheme 12). ${ }^{23}$ Electrondonating and electron-withdrawing groups of 2-alkynylbenzaldehydes $\mathbf{5 7}$ showed low impact on the reaction efficacy affording the target compounds $\mathbf{5 8}$ in good to excellent and moderate to excellent yields, respectively.
Scheme 12<smiles>[R]C#Cc1ccccc1C=O</smiles>

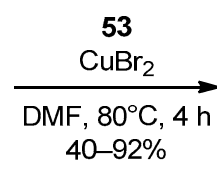<smiles>[R]C1=Cc2ccccc2C2NC(=O)c3cccn3N12</smiles>

$\mathrm{R}=\mathrm{Ph}, 4-\mathrm{MeOC}_{6} \mathrm{H}_{4}, 4-\mathrm{O}_{2} \mathrm{NC}_{6} \mathrm{H}_{4}$, cyclopropyl

Compounds 60 were obtained via $\mathrm{Cu}(\mathrm{II})$-promoted cyclization of $N$-aminopyrroles $\mathbf{5 3}$ or $\mathbf{5 9}$ with aryl aldehydes upon heating in DMSO in moderate to good yields (Scheme 13). ${ }^{24}$ Electron-donating groups of aryl aldehyde accelerated the process as compared to electronwithdrawing substituents.

Scheme 13<smiles>[R][R]1ccc(-c2nn3cc([R])cc3c(=O)[nH]2)cc1</smiles>
$\mathrm{R}^{2}=\mathrm{H}, 4-\mathrm{Me}, 4-\mathrm{NO}_{2}, 3-\mathrm{MeO}, 3-\mathrm{Br}, 3-\mathrm{NO}_{2}, 2-\mathrm{MeO}, 2-\mathrm{Br}$

\section{Synthesis via rearrangement of pyrrolooxadiazines}

A practical synthesis of pyrrolo[2,1-f][1,2,4]triazin$4(3 H)$-ones has been proposed via rearrangement of pyrrolo$[1,2-d][1,3,4]$ oxadiazines. ${ }^{25}$ The methodology involved synthesis of pyrrole-2-carboxamides 62 from 3-chloro$1 H$-pyrrole-2-carboxylic acid (61) (Scheme 14). Treating

\section{Scheme 14}
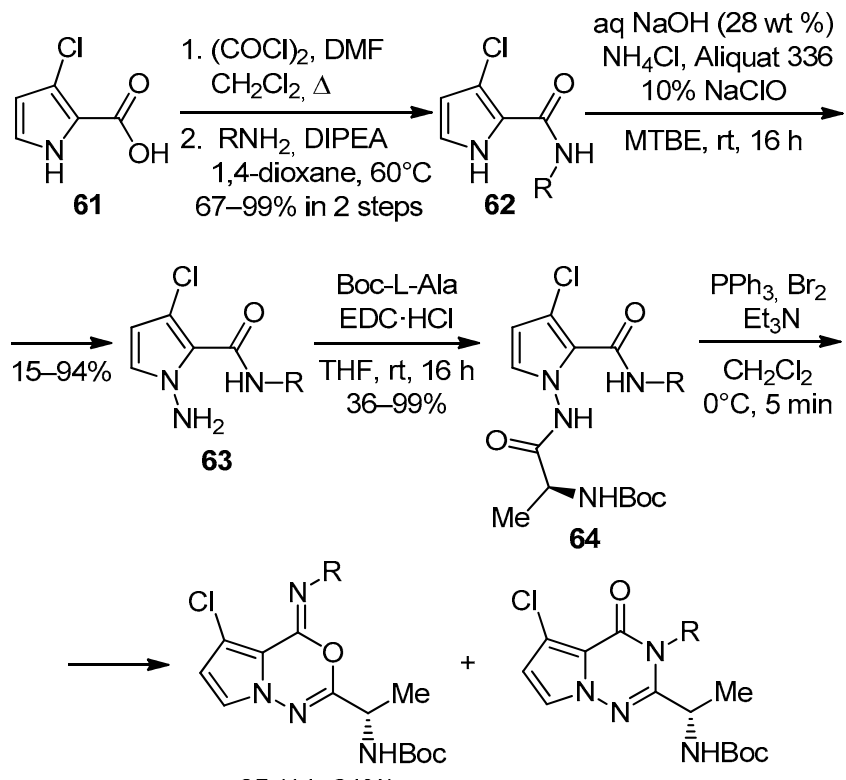

$65(11-81 \%)$<smiles>[R]n1c([C@H](C)NC(=O)O)nn2ccc(Cl)c2c1=O</smiles>
$66(10-68 \%)$

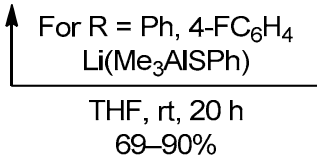

$\mathrm{R}=\mathrm{Ph}, 2-\mathrm{FC}_{6} \mathrm{H}_{4}, 3-\mathrm{FC}_{6} \mathrm{H}_{4}, 4-\mathrm{FC}_{6} \mathrm{H}_{4}, 4-\mathrm{MeOC}_{6} \mathrm{H}_{4}, 4-\mathrm{NCC}_{6} \mathrm{H}_{4}$, 4- $\mathrm{MeOC}_{6} \mathrm{H}_{4} \mathrm{CH}_{2}$, cyclopropyl 
pyrroles 62 with $\mathrm{NH}_{4} \mathrm{Cl}$, Aliquat 336, and $\mathrm{NaClO}$ afforded 1 -aminopyrroles 63. Interaction of compounds 63 with $\mathrm{EDC} \cdot \mathrm{HCl}$ and Boc-L-Ala yielded pyrrole derivatives $\mathbf{6 4}$. Regioselective intramolecular cyclization of pyrroles 64 upon treatment with $\mathrm{PPh}_{3}, \mathrm{Br}_{2}$, and $\mathrm{Et}_{3} \mathrm{~N}$ in $\mathrm{CH}_{2} \mathrm{Cl}_{2}$ gave a mixture of the desired compounds 65 and side products 66. The latter were further converted to the desired products $\mathbf{6 5}$ using lithium trimethyl(phenylsulfido)aluminate in THF (Scheme 14).

In conclusion, pyrrolo[2,1-f][1,2,4]triazines are important scaffolds with a broad range of biological activities. This review is an attempt to present the current synthetic strategies adopted for the synthesis of pyrrolo[2,1-f][1,2,4]triazine derivatives. As evident from the methods available in the literature, there are several efficient routes to synthesize pyrrolo[2,1-f][1,2,4]triazine derivatives. Despite tremendous potential of this moiety, the number of pyrrolo$[2,1-f][1,2,4]$ triazines is currently very limited. Thus, there is a huge potential for the synthesis of novel products containing pyrrolo[ $[2,1-f][1,2,4]$ triazine moiety that are more potent in pharmaceutical applications. Moreover, taking into account the recent interest generated by remdesivir, a potential antiviral drug used to treat COVID-19 infection, we believe that there will be renewed efforts to develop more facile synthetic strategies for pyrrolo[2,1-f]$[1,2,4]$ triazine derivatives.

\section{References}

1. Wang, M.; Cao, R.; Zhang, L.; Yang, X.; Liu, J.; Xu, M.; Shi, Z.; Hu, Z.; Zhong, W.; Xiao, G. Cell Res. 2020, 30, 269.

2. Kim, K. S.; Lu, S.; Cornelius, L. A.; Lombardo, L. J.; Borzilleri, R. M.; Schroeder, G. M.; Sheng, C.; Rovnyak, G.; Crews, D.; Schmidt, R. J.; Williams, D. K.; Bhide, R. S.; Traeger, S. C.; McDonnell, P. A.; Mueller, L.; Sheriff, S.; Newitt, J. A.; Pudzianowski, A. T.; Yang, Z.; Wild, R.; Lee, F. Y.; Batorsky, R.; Ryder, J. S.; Ortega-Nanos, M.; Shen, H.; Gottardis, M.; Roussell, D. L. Bioorg. Med. Chem. Lett. 2006, 16, 3937.

3. Borzilleri, R. M.; Cai, Z.-W.; Ellis, C.; Fargnoli, J.; Fura, A.; Gerhardt, T.; Goyal, B.; Hunt, J. T.; Mortillo, S.; Qian, L.; Tokarski, J.; Vyas, V.; Wautlet, B.; Zheng, X.; Bhide, R. S. Bioorg. Med. Chem. Lett. 2005, 15, 1429.

4. Shi, W.; Qiang, H.; Huang, D.; Bi, X.; Huang, W.; Qian, H. Eur. J. Med. Chem. 2018, 158, 814.

5. Hunt, J. T.; Mitt, T.; Borzilleri, R.; Gullo-Brown, J.; Fargnoli, J.; Fink, B.; Han, W.-C.; Mortillo, S.; Vite, G.; Wautlet, B.; Wong, T.; Yu, C.; Zheng, X.; Bhide, R. J. Med. Chem. 2004, 47, 4054.

6. Mesaros, E. F.; Angeles, T. S.; Albom, M. S.; Wagner, J. C.; Aimone, L. D.; Wan, W.; Lu, L.; Huang, Z.; Olsen, M.; Kordwitz, E.; Haltiwanger, R. C.; Landis, A. J.; Cheng, M.; Ruggeri, B. A.; Ator, M. A.; Dorsey, B. D.; Ott, G. R. Bioorg. Med. Chem. Lett. 2015, 25, 1053.

7. Sampognaro, A. J.; Wittman, M. D.; Carboni, J. M.; Chang, C.; Greer, A. F.; Hurlburt, W. W.; Sack, J. S.; Vyas, D. M. Bioorg. Med. Chem. Lett. 2010, 20, 5027.

8. Abraham, S.; Hadd, M. J.; Tran, L.; Vickers, T.; Sindac, J.; Milanov, Z. V.; Holladay, M. W.; Bhagwat, S. S.; Hua, H.; Pulido, J. M. F.; Cramer, M. D.; Gitnick, D.; James, J.; Dao, A.;
Belli, B.; Armstrong, R. C.; Trieber, D. K.; Liu, G. Bioorg. Med. Chem. Lett. 2011, 21, 5296.

9. Fink, B. E.; Vite, G. D.; Mastalerz, H.; Kadow, J. F.; Kim, S.-H.; Leavitt, K. J.; Du, K.; Crews, D.; Mitt, T.; Wong, T. W.; Hunt, J. T.; Vyas, D. M.; Tokarski, J. S. Bioorg. Med. Chem. Lett. 2005, 15, 4774.

10. Xin, M.; Zhang, L.; Tang, F.; Tu, C.; Wen, J.; Zhao, X.; Liu, Z.; Cheng, L.; Shen, H. Bioorg. Med. Chem.2014, 22, 1429.

11. Siegel, D.; Hui, H. C.; Doerffler, E.; Clarke, M. O.; Chun, K.; Zhang, L.; Neville, S.; Carra, E.; Lew, W.; Ross, B.; Wang, Q.; Wolfe, L.; Jordan, R.; Soloveva, V.; Knox, J.; Perry, J.; Perron, M.; Stray, K. M.; Barauskas, O.; Feng, J. Y.; Xu, Y.; Lee, G.; Rheingold, A. L.; Ray, A. S.; Bannister, R.; Strickley, R.; Swaminathan, S.; Lee, W. A.; Bavari, S.; Cihlar, T.; Lo, M. K.; Warren, T. K.; Mackman, R. L. J. Med. Chem. 2017, 60, 1648.

12. Li, Q.; Groaz, E.; Rocha-Pereira, J.; Neyts, J.; Herdewijn, P. Eur. J. Med. Chem. 2020, 195.

13. Wrobleski, S. T.; Lin, S.; Hynes, J., Jr.,; Wu, H.; Pitt, S.; Shen, D. R.; Zhang, R.; Gillooly, K. M.; Shuster, D. J.; Mclntyre, K. W.; Doweyko, A. M.; Kish, K. F.; Tredup, J. A.; Duke, G. J.; Sack, J. S.; McKinnon, M.; Dodd, J.; Barrish, J. C.; Schieven, G. L.; Leftheris, K. Bioorg. Med. Chem. Lett. 2008, $18,2739$.

14. Ji, Z.; Dai, Y.; Abad-Zapatero, C.; Albert, D. H.; Bouska, J. J.; Glaser, K. B.; Marcotte, P. A.; Soni, N. B.; Magoc, T. J.; Stewart, K. D.; Wei, R.-Q.; Davidsen, S. K.; Michaelides, M. R. Bioorg. Med. Chem. Lett. 2012, 22, 4528.

15. Borzilleri, R. M.; Zheng, X.; Qian, L.; Ellis, C.; Cai, Z.; Wautlet, B. S.; Mortillo, S.; Jeyaseelan, R.; Kukral, D. W.; Fura, A.; Kamath, A.; Vyas, V.; Tokarski, J. S.; Barrish, J. C.; Hunt, J. T.; Lombardo, L. J.; Fargnoli, J.; Bhide, R. S. J. Med. Chem. 2005, 48, 3991.

16. Thieu, T.; Sclafani, J. A.; Levy, D. V.; McLean, A.; Breslin, H. J.; Ott, G. R.; Bakale, R. P.; Dorsey, B. D. Org. Lett. 2011, 13, 4204.

17. Wang, M.; Gao, M.; Zheng, Q.-H. Bioorg. Med. Chem. Lett. 2014, 24, 3700 .

18. Zheng, B.; Conlon, D. A.; Corbett, R. M.; Chau, M.; Hsieh, D.-M.; Yeboah, A.; Hsieh, D.; Müslehiddinoğu, J.; Gallagher, W. P.; Simon, J. A.; Burt, J. Org. Proc. Res. Dev. 2012, 16, 1846.

19. Lim, J.; Altman, M. D.; Baker, J.; Brubaker, J. D.; Chen, H.; Chen, Y.; Kleinschek, M. A.; Li, C.; Liu, D.; Maclean, J. K. F.; Mulrooney, E. F.; Presland, J.; Rakhilina, L.; Smith, G. F.; Yang, R. Bioorg. Med. Chem. Lett. 2015, 25, 5384.

20. Draffan, A. G.; Frey, B.; Pool, B.; Gannon, C.; Tyndall, E. M.; Lilly, M.; Francom, P.; Hufton, R.; Halim, R.; Jahangiri, S.; Bond, S.; Nguyen, V. T. T.; Jeynes, T. P.; Wirth, V.; Luttick, A.; Tilmanis, D.; Thomas, J. D.; Pryor, M.; Porter, K.; Morton, C. J.; Lin, B.; Duan, J.; Kukolj, G.; Simoneau, B.; McKercher, G.; Lagacé, L.; Amad, M.; Bethell, R. C.; Tucker, S. P. ACS Med. Chem. Lett. 2014, 5, 679.

21. Xiang, H.-Y.; Chen, Y.-H.; Wang, Y.; Zhang, X.; Ding, J.; Meng, L.-H.; Yang, C.-H. Bioorg. Med. Chem. Lett. 2020, 30. https://doi.org.10.1016/j.bmcl.2020.127194.

22. Xiang, H.; Chen, Y.; He, Q.; Xie, Y.; Yang, C. RSC $A d v$. 2013, 35807.

23. Chen, J.; Liu, B.; Chen, Y.; He, Q.; Yang, C. RSC Adv. 2014, 4, 11168.

24. Chen, Y.; Xiang, H.; Tan, C.; Xie, Y.; Yang, C. Tetrahedron 2013, 69, 2714.

25. Son, K.; Park, S. J. Beilstein J. Org. Chem. 2016, 12, 1780. 